Acta Technologica Agriculturae 2

Nitra, Slovaca Universitas Agriculturae Nitriae, 2020, pp. 60-66

\title{
ENERGY REQUIREMENT OPTIMIZATION OF GREENHOUSE VEGETABLE PRODUCTION USING DATA ENVELOPMENT ANALYSIS (DEA) METHOD IN ALGERIA
}

\author{
Ahmed NOURANI ${ }^{1 *}$, Abdelaali BENCHEIKH ${ }^{2}$

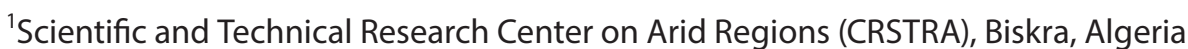 \\ ${ }^{2}$ University of Ahmed Draia Adrar, Algeria
}

\begin{abstract}
Algeria has recently experienced an important agricultural development in terms of gardening in plastic greenhouses thanks to the favourable factors (climatic conditions, etc.). In order to optimize the energy requirements, data from 29 farmers were collected, who qualitatively represent the greenhouse vegetable producers from the most productive sub-provinces of Biskra region (south of Algeria). Considering the various parametric and non-parametric methods for energy consumption optimization, data envelopment analysis is the most common non-parametric method applied. Results showed that the mean radial technical efficiency assumptions of the samples under constant returns to scale and variable returns to scale models were 0.88 and 0.98 , respectively. The $51.72 \%$ of decision-making units were efficient on the basis of the constant returns to scale model; $79.31 \%$ decision-making units were observed efficient on the basis of variable returns to scale model. Calculation of optimal energy requirements for vegetable greenhouse indicated that $108.50 \mathrm{GJ}^{-h^{-1}}$ can be saved on machinery $\left(1.38 \mathrm{GJ}^{-}\right.$.ha $\left.{ }^{-1}\right)$; diesel fuel $\left(4.68 \mathrm{GJ} \cdot \mathrm{ha}^{-1}\right)$; infrastructure $\left(9.35 \mathrm{GJ} \cdot \mathrm{ha}^{-1}\right)$; fertilizers $\left(17.08 \mathrm{GJ} \cdot \mathrm{ha}^{-1}\right)$; farmyard manure $\left(12.05 \mathrm{GJ} \cdot \mathrm{ha}^{-1}\right)$; pesticides $\left(3.93 \mathrm{GJ} \cdot \mathrm{ha} \mathrm{H}^{-1}\right)$; and electricity $\left(60.03 \mathrm{GJ}^{\circ} \mathrm{ha}^{-1}\right)$.
\end{abstract}

Keywords: greenhouse cultivation; input-output analysis; Biskra; DEA; Algeria

During the last twenty years, Algeria showed a significant agricultural development caused by prosperous gardening in plastic greenhouses thanks to the favourable climatic conditions and the governmental policy (Nourani and Bencheikh, 2017). As results of this development, Biskra province became the most significant producer of early vegetables nationally (Allache et al., 2015); the area occupied by the greenhouses increased by $528.52 \%$ over the last 20 years (Belhadi et al., 2016). Greenhouses are constructed for the purpose of achieving the controlled environment suitable for crop production (Akpenpuun and Mijinyawa, 2018).

Agriculture is both a producer and consumer of energy (Bahrami et al., 2011). It utilizes large amounts of locally available non-commercial energies, such as seeds, manure, etc., as well as commercial energies in form of diesel fuel; electricity; fertilizers; irrigation water; etc. (Kizilaslan, 2009). Efficient exploitation of energies allows the achievement of increments in production and productivity and contributes to the economy, profitability and competitiveness of agriculture sustainability in rural living (Singh et al., 2002). Multiple authors have dealt with energy consumption optimization in greenhouses, e.g. for vegetable production (Firoozi et al., 2014), for cucumber production (Banaeian et al., 2012); however, there has not been published a study on energy input-output efficiency optimization of greenhouse vegetable production in MENA region. Furthermore, no papers published took into account that infrastructure can be a considerable input in energy analyses.

With these observations in mind, this study is focused on the determination of the energy use efficiency, wasteful use of energy and selected energy requirements for greenhouse vegetable production in Biskra province, in the south of Algeria, in order to optimize the energy consumption.

\section{Material and methods}

\section{Survey}

According to Rekibi (2015), Biskra province is responsible for more than $32 \%$ of national production of protected crops, making it the most significant producer of early vegetables in Algeria. Therefore, this study was conducted in this region specifically for this reason. It took place in Biskra province during the 2014-2015 season and employed face-toface personal interviews via questionnaires consisting of sections aimed at the economic characteristics, practices, and farm management. There were 29 farmers - qualitatively representing the producers of greenhouse vegetables in the most productive sub-provinces of Biskra - who participated in interviews. The most frequently produced vegetables in these sub-provinces include tomatoes; cucumbers; eggplants; and pepper. 


\section{Energy pattern}

Agricultural energy requirements can be divided into two groups: direct (human labour; diesel fuel; water for irrigation; etc.) and indirect (seeds; fertilizers; farmyard manure; chemicals; machinery; infrastructure; etc.). On the basis of the energy equivalents of inputs and outputs (Table 1), metabolisable energy was calculated.

In order to analyse the energy flow, energy ratio (energy use efficiency, ER); net energy $(N E)$; energy productivity $(E P)$; and specific energy indices were calculated as follows:

$$
\begin{aligned}
& \text { output }- \text { input ratio }(E R)=\frac{\text { energy output }\left(\mathrm{MJ} \cdot \mathrm{ha}^{-1}\right)}{\text { energy input }\left(\mathrm{MJ} \cdot \mathrm{ha}^{-1}\right)} \\
& \text { energy productivity }(E P)=\frac{\text { total output }\left(\mathrm{kg} \cdot \mathrm{ha}^{-1}\right)}{\text { energy input }\left(\mathrm{MJ} \cdot \mathrm{ha}^{-1}\right)}
\end{aligned}
$$

net energy $(N E)=$ energy output $\left(\mathrm{MJ} \cdot \mathrm{ha}^{-1}\right)$ - energy input $\left(\mathrm{MJ} \cdot \mathrm{ha}^{-1}\right)$

$$
\text { specific energy }=\frac{\text { energy input }\left(\mathrm{MJ} \cdot \mathrm{ha}^{-1}\right)}{\text { vegetable output }\left(\mathrm{kg} \cdot \mathrm{ha}^{-1}\right)}
$$

\begin{tabular}{|c|c|c|c|}
\hline Energy source & Unit & $\begin{array}{l}\text { Energy equivalent } \\
\left(\text { Mj.unit }^{-1}\right)\end{array}$ & Reference \\
\hline \multicolumn{4}{|l|}{ Inputs } \\
\hline Human labour & $\mathrm{h}$ & 1.96 & Singh et al. (2002) \\
\hline Machinery & $\mathrm{h}$ & 62.7 & Singh et al. (2002) \\
\hline Diesel fuel & I & 45.4 & Bojacá et al. (2012) \\
\hline \multicolumn{4}{|l|}{ Infrastructure } \\
\hline - Steel & \multirow[t]{4}{*}{$\mathrm{kg}$} & 33 & Medina et al. (2006) \\
\hline - Polyethylene & & 9.9 & Medina et al. (2006) \\
\hline - Synthetic fibre & & 1.2 & Medina et al. (2006) \\
\hline -PVC & & 11.6 & Medina et al. (2006) \\
\hline \multicolumn{4}{|l|}{ Fertilizers } \\
\hline$-\mathbf{N}$ & \multirow[t]{3}{*}{$\mathrm{kg}$} & 60.6 & Ozkan et al. (2004) \\
\hline$-P_{2} O_{5}$ & & 11.1 & Ozkan et al. (2004) \\
\hline$-\mathrm{K}_{2} \mathrm{O}$ & & 6.7 & Ozkan et al. (2004) \\
\hline Farmyard manure & $\mathrm{kg}$ & 0.3 & Bojacá et al. (2012) \\
\hline \multicolumn{4}{|l|}{ Pesticides } \\
\hline - Fungicides & \multirow[t]{2}{*}{$\mathrm{kg}$} & 216 & Mohammadi and Omid (2010) \\
\hline - Insecticides & & 101.2 & Mohammadi and Omid (2010) \\
\hline \multicolumn{4}{|l|}{ Plant materials } \\
\hline - Plantlets & unit & 0.2 & Bojacá et al. (2012) \\
\hline Water for irrigation & $\mathrm{m}^{3}$ & 0.63 & Bojacá et al. (2012) \\
\hline Electricity & $\mathrm{kW} \cdot \mathrm{h}^{-1}$ & 3.6 & Ozkan et al. (2004) \\
\hline \multicolumn{4}{|l|}{ Output } \\
\hline $\begin{array}{l}\text { Tomato, cucumber, } \\
\text { eggplant, pepper }\end{array}$ & $\mathrm{kg}$ & 0.8 & Ozkan et al. (2004) \\
\hline
\end{tabular}

Table 1 Energy equivalents of inputs and outputs in greenhouse vegetable production

\section{Data envelopment analysis (DEA)}

In terms of the various parametric and non-parametric methods for the energy consumption optimization, DEA is the most common method applied. Since its introduction, the DEA method has shown an exponential success: Emrouznejad et al. (2008) identified more than 4,000 published research articles on the DEA method in scientific journals or reference books. According to Huguenin (2013), this method was developed in order to evaluate the efficiency of a US federal program of resource allocation to schools ("Program Follow Through").

The DEA method makes it possible to evaluate the performance of the organizations (i.e. decision-making units - DMUs) that transform resources (inputs) into benefits (outputs). Its detailed description can be found in Banaeian et al. (2012).

Two basic models are utilized in DEA, each leading to the identification of a different efficiency frontier. The first model assumes that organizations evolve in a situation of constant returns to scale (CRS). According to this model, it is appropriate for all organizations to reach their optimal size (Charnes et al., 1978). The second model assumes that organizations evolve in a situation of variable returns to scale (VRS). In terms of this model, it is appropriate when organizations do not operate at their optimal size (Banker et al., 1984).

In order to select the inputs for DEA approach, a linear regression analysis for determination of effective energy inputs on yield was performed. The function used was of Cobb-Douglas production function form expressed as follows (Singh et al., 2004; Hatirli et al., 2006; Mohammadi and Omid, 2010; Banaeian et al., 2012):

$$
Y_{i}=\alpha_{0}+\sum_{i=1}^{7} \alpha_{j}\left(x_{i j}\right)+e_{i} ; i=1,2,3 \ldots 29
$$

where:

$Y_{i}-i_{\text {th }}$ greenhouse yield

$x_{i j}$ - vector of energy inputs used in the production process $\left(x_{i 1}\right.$ - human labour, $x_{i 2}-$ machinery, $x_{i 3}$ - diesel fuel, $x_{i 4}-$ infrastructure, $x_{i 5}$ - fertilizer, $x_{i 6}$ - pesticide, $x_{i 7}$ - farmyard manure, $x_{i 8}-$ plantlets, $x_{i 9}$ - water for irrigation, $x_{i 10}$ - electricity) 
$\alpha_{0}$ - constant term

$\alpha_{j}$ - coefficient of energy inputs which are estimated from the model

This function and its variations have been used by multiple authors (Singh et al., 2004; Hatirli et al., 2006; Mohammadi and Omid, 2010; Banaeian et al., 2012) to examine the relationship between input energy and yield.

In this study, input-oriented DEA seems more appropriate, given that it is more reasonable to argue that a farmer has more control over inputs rather than outputs in the agricultural sector (Nabavi-Pelesaraei et al., 2014).

\section{Technical efficiency (TE)}

Technical efficiency is a global measure of a DMU performance. The TE can be defined as follows (NabaviPelesaraei et al., 2014):

$$
T E_{j}=\frac{u_{1} y_{1 j}+u_{2} y_{2 j} \ldots u_{n} y_{n j}}{v_{1} x_{1 j}+v_{2} x_{2 j} \ldots v_{n} x_{n j}}=\frac{\sum_{r=1}^{n} u_{r} y_{r j}}{\sum_{s=1}^{m} v_{s} x_{s j}}
$$

where:

$u_{r}$ - weight given to output $n$

$y_{r} \quad$ - amount of output $n$

$v_{s} \quad$ - weight given to input $n$

$x_{s}$ - amount of input $n$

$r \quad$ - number of outputs $(r=1,2 \ldots, n)$

$s \quad-$ number of inputs $(s=1,2 \ldots, m)$

$j-j^{\text {th }}$ of DMUs $(j=1,2 \ldots, k)$

To solve the Eq. 1, following linear programming (LP) was formulated:

Maximize: $\theta=\sum_{r=1}^{n} u_{r} y_{j}$

Subjected to $\sum_{r=1}^{n} u_{r} y_{j}-\sum_{s=1}^{m} v_{s} x_{s j} \leq 0$

$\sum_{s=1}^{m} v_{s} x_{s j}=1$

$$
u_{r} \geq 0, v_{s} \geq 0, \wedge
$$

where:

$\theta \quad$ - technical efficiency

Model (3) is known as the input-oriented CRS DEA model - it assumes constant returns to scale (CRS) (NabaviPelesaraei et al., 2014).

\section{Scale efficiency (SE)}

The SE relates to the most efficient scale of operations in the sense of maximizing the average productivity (Firoozi et al., 2014). Furthermore, scale efficiency represents the potential productivity gain from achieving the optimal size of a DMU (Reyhani-Farashah et al., 2013). The relationship between technical and pure technical efficiency scores can be described by the next formula (Mousavi-Avval et al., 2011):

$$
\text { scale efficiency }=\frac{\text { technical efficiency }}{\text { pure technical efficiency }}
$$

Considering the analysis of efficient and inefficient DMUs, the energy-saving target ratio (ESTR) index can be used, which represents the inefficiency level for each DMU with respect to the energy consumption (Nourani and Bencheikh, 2017). The formula for it is as follows (Firoozi et al., 2014):

$$
E S T R_{j}=\frac{\text { energy saving } \text { target }_{j}}{\text { actual energy input }}{ }_{j}
$$

The aim is to save energy by overall reduction in inputs without decreasing the outputs $\left(j-j^{\text {th }} \mathrm{DMU}\right)$.

The majority of calculation was performed by means of the free application Win4Deap 2, version 2.1.

\section{Results and discussion}

Data were collected from 29 protected vegetable producers in Biskra province. The average size of a local greenhouse is approx. 2.1 ha with a range from 0.25 up to 12.75 ha. Observed greenhouses were made of plastic and had metallic structure. Furthermore, the data showed that majority of greenhouses utilized drip irrigation and approx. $73 \%$ of farms were privately owned and $27 \%$ rented.

The survey was actually conducted with a higher number of farmers - 65 - since there are two essential drawbacks of deterministic frontier models: both nonparametric and parametric models are very sensitive to outliers and extreme values; and noisy data is not allowed (Pahlavan et al., 2011). Therefore, higher number of farmers was selected in order to assure homogeneity on the basis of a specific area character.

By means of Eq. 1, $R^{2}=0.92$ was given by regression analysis of performance. All significant inputs, such as human labour; plantlets; etc., were taken into account; and analysis adopted the significant inputs and assumed seven input variables: infrastructure; fertilizers; farmyard

Table 2 Statics description of adopted inputs and output (Mj·ha ${ }^{-1}$ )

\begin{tabular}{|l||c|c|c|c|c|c|c|c|}
\hline & Machinery & Diesel fuel & Infrastructure & Fertilizers & $\begin{array}{c}\text { Farmyard } \\
\text { manure }\end{array}$ & Pesticide & Electricity & Yield \\
\hline \hline Max. & 3,762 & $36,178.12$ & $341,728.22$ & 252,036 & 27,720 & $101,020.73$ & $281,842.10$ & 200,000 \\
\hline Min. & 627 & 425.62 & $7,801.08$ & $1,873.52$ & 2,700 & 1,386 & $1,043.85$ & 50,000 \\
\hline Mean & $1,729.65$ & $5,107.5$ & $22,008.94$ & $26,990.68$ & $13,379.58$ & $12,164.44$ & $84,654.37$ & $113,724.13$ \\
\hline SD & 742.39 & $7,414.62$ & $61,502.86$ & $46,145.70$ & $6,725.31$ & $20,590.45$ & $70,952.94$ & $36,756.82$ \\
\hline
\end{tabular}


manure; electricity; diesel fuel; pesticides; and machinery energy, which represent major energy inputs having impact on vegetable yield in the studied greenhouses, with $91 \%$ of total energy used. These are given in Table 2 with descriptive statistics for 29 vegetable producers. According to Cooper et al. (2001), the number of DMUs should be at least three times the total number of input and output factors taken into account when using the DEA model (Banaeian et al., 2012); therefore, this study works with a number of greenhouses that is three times the number of selected eight input-output variables for the performance model.

\section{Technical, pure technical and scale efficiency of greenhouses}

Table 3 describes the results acquired by means of inputoriented DEA. The mean radial TEs of the samples under CRS and VRS assumptions were 0.88 and 0.98 , respectively. Moreover, $51.72 \%$ of DMUs (15 units) were observed efficient on the basis of CRS model; whereas, on the basis of VCR model, score of the pure TE was shown by $79.31 \%$ of DMUs (23 units). This implies that, in average, vegetable greenhouses can reduce their inputs by $12 \%$ (2\%) and still maintain the identical output level - increasing of the greenhouse TE actually results in lower input usage,

Table 3 Results of the technical efficiency scores (technical, pure, and scale) and returns to scale

\begin{tabular}{|c|c|c|c|c|c|c|c|c|c|c|c|}
\hline \multirow{2}{*}{$\sum_{0}^{?}$} & \multirow{2}{*}{ 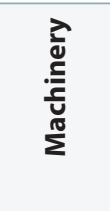 } & \multirow{2}{*}{ 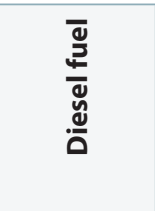 } & \multirow{2}{*}{ 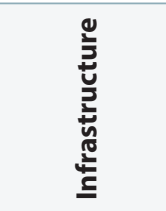 } & \multirow{2}{*}{ 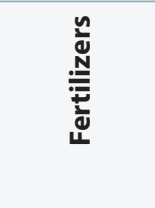 } & \multirow{2}{*}{ 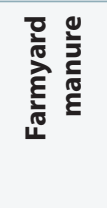 } & \multirow{2}{*}{$\frac{\tilde{y}}{\frac{\tilde{o}}{0}}$} & \multirow{2}{*}{ 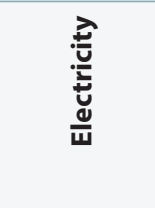 } & \multicolumn{2}{|c|}{ Technical efficiency } & \multirow{2}{*}{ 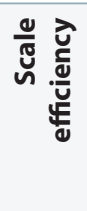 } & \multirow{2}{*}{$\stackrel{\check{L}}{\check{L}}$} \\
\hline & & & & & & & & 气̛ & $\stackrel{\varkappa}{\check{c}}$ & & \\
\hline 1 & 1,254 & 11,350 & $10,441.916$ & $75,340.40$ & 18,168 & $12,459.360$ & $14,092.105$ & 1 & 1 & 1 & \\
\hline 2 & $3,030.5$ & $36,178.125$ & $9,556.495$ & $63,917.96$ & 16,818 & $18,556.128$ & $2,947.368$ & 1 & 1 & 1 & \\
\hline 3 & 2,508 & $14,896.875$ & $10,289.178$ & $9,968.16$ & 4,800 & $1,764.720$ & $10,736.842$ & 1 & 1 & 1 & \\
\hline 4 & 1,254 & 2,270 & $9,854.416$ & $1,873.52$ & 13,650 & $2,891.928$ & $58,717.105$ & 1 & 1 & 1 & \\
\hline 5 & 1,463 & 851.25 & $12,727.083$ & $16,576.72$ & 8,400 & $6,128.760$ & $93,947.368$ & 0.825 & 1 & 0.825 & IRS \\
\hline 6 & 1,463 & $16,315.625$ & $10,246.330$ & $33,302.32$ & 8,550 & $11,760.30$ & $10,892.449$ & 0.918 & 1 & 0.918 & IRS \\
\hline 7 & 1,254 & $1,418.75$ & $10,292.416$ & $26,807.72$ & 22,230 & $5,969.250$ & $156,578.95$ & 0.726 & 0.924 & 0.786 & IRS \\
\hline 8 & 3,135 & 5,675 & $10,596.916$ & $10,747.68$ & 16,800 & $3,841.354$ & $36,013.158$ & 1 & 1 & 1 & \\
\hline 9 & 1,045 & $7,093.75$ & $10,512.416$ & $15,587.32$ & 11,076 & $2,500.050$ & $125,263.16$ & 0.964 & 1 & 0.964 & IRS \\
\hline 10 & 627 & $2,128.125$ & $11,211.083$ & $13,345.80$ & 6,816 & $1,386.000$ & $50,105.263$ & 1 & 1 & 1 & \\
\hline 11 & 1,881 & $2,128.125$ & $11,040.416$ & $13,320.64$ & 8,400 & $2,023.152$ & $156,578.94$ & 1 & 1 & 1 & \\
\hline 12 & 3,762 & $7,803.125$ & $10,424.416$ & $19,341.92$ & 22,800 & $10,602.576$ & $10,248.804$ & 0.83 & 0.941 & 0.882 & IRS \\
\hline 13 & $2,821.5$ & $8,512.5$ & $9,085.083$ & $11,212.08$ & 14,820 & $3,973.050$ & $1,043.860$ & 1 & 1 & 1 & \\
\hline 14 & 1,881 & $9,931.25$ & $10,300.988$ & $3,403.76$ & 22,230 & $5,996.160$ & $10,736.842$ & 1 & 1 & 1 & \\
\hline 15 & 2,090 & $2,837.5$ & $341,728.221$ & $252,036.00$ & 2,700 & $4,272.000$ & $54,802.632$ & 0.639 & 1 & 0.639 & IRS \\
\hline 16 & 1,881 & $1,702.5$ & $7,801.083$ & $12,439.20$ & 15,270 & $11,579.814$ & $78,289.474$ & 0.82 & 1 & 0.82 & IRS \\
\hline 17 & 1,672 & $1,418.75$ & $10,160.416$ & $27,224.08$ & 4,200 & $3,966.480$ & $187,894.73$ & 1 & 1 & 1 & \\
\hline 18 & 1,672 & $1,418.75$ & $10,820.416$ & $26,136.52$ & 4,200 & $3,257.280$ & $75,157.895$ & 1 & 1 & 1 & \\
\hline 19 & 1,463 & $2,837.5$ & $10,906.416$ & $5,535.44$ & 16,800 & $101,020.73$ & $281,842.10$ & 0.453 & 0.878 & 0.516 & IRS \\
\hline 20 & 1,254 & $1,702.5$ & $11,455.750$ & $4,346.96$ & 8,550 & $2,516.580$ & $67,850.877$ & 1 & 1 & 1 & \\
\hline 21 & $1,985.5$ & $1,418.75$ & $10,112.416$ & $18,032.00$ & 2,940 & $14,253.278$ & $56,368.421$ & 0.591 & 1 & 0.591 & IRS \\
\hline 22 & 1,881 & 709.375 & $11,432.416$ & $20,359.00$ & 22,230 & $46,751.400$ & $250,526.31$ & 0.67 & 0.854 & 0.785 & IRS \\
\hline 23 & 1,254 & 993.125 & $10,678.131$ & $18,431.40$ & 17,100 & $1,729.740$ & $89,473.684$ & 1 & 1 & 1 & \\
\hline 24 & 627 & 425.625 & $13,082.416$ & $14,296.72$ & 27,720 & $2,460.530$ & $93,947.368$ & 1 & 1 & 1 & \\
\hline 25 & $1,567.5$ & 993.125 & $13,012.988$ & $9,481.60$ & 18,900 & $48,045.600$ & $89,473.684$ & 0.663 & 0.989 & 0.670 & IRS \\
\hline 26 & 1,881 & $1,276.875$ & $10,575.528$ & $5,912.74$ & 9,810 & $7,297.476$ & $93,947.368$ & 0.808 & 1 & 0.808 & IRS \\
\hline 27 & 1,254 & 851.25 & $12,164.416$ & $13,343.20$ & 15,750 & $4,879.392$ & $125,263.16$ & 0.668 & 0.99 & 0.675 & IRS \\
\hline 28 & 731.5 & 2,270 & $9,875.166$ & $21,634.64$ & 12,600 & $2,632.320$ & $46,973.684$ & 1 & 1 & 1 & \\
\hline 29 & $1,567.5$ & 709.375 & $7,874.416$ & $18,774.40$ & 13,680 & $8,253.600$ & $125,263.16$ & 0.838 & 1 & 0.838 & IRS \\
\hline
\end{tabular}




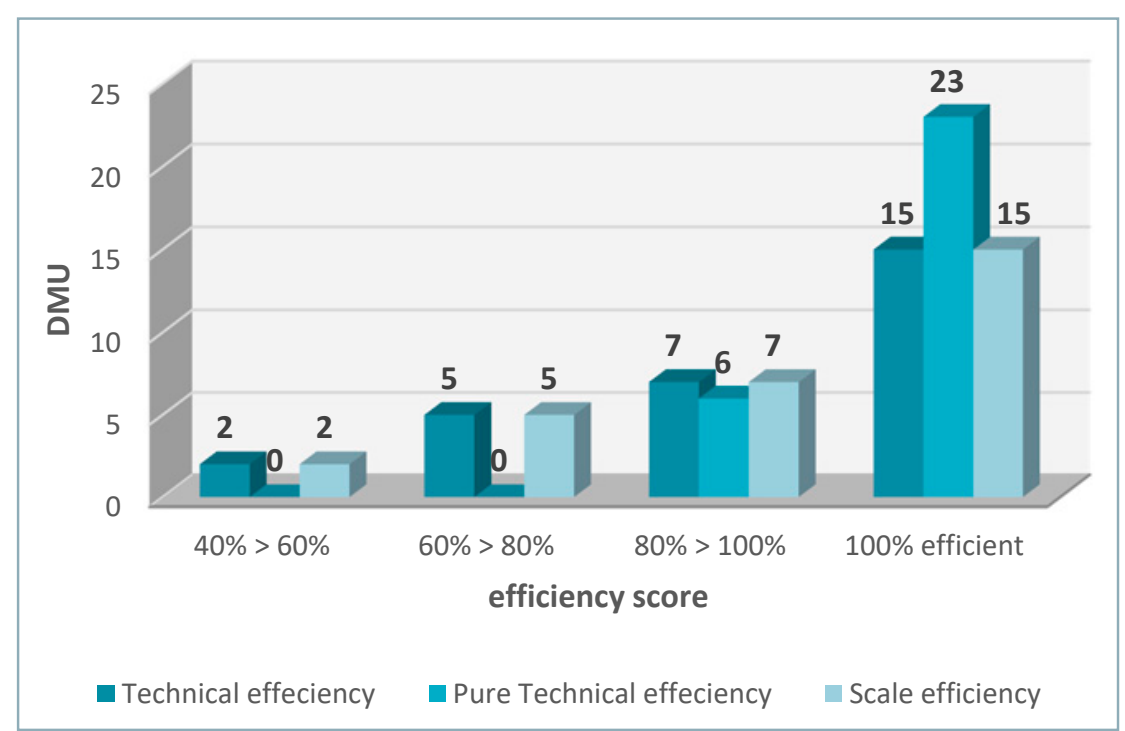

Fig. 1 Efficiency score distribution

production costs and higher profits, which is a motivation for producers to adopt new methods and technology (Firoozi et al., 2014).

Employing the Eq. 8, it is obvious that the scale efficiency equals to 1 for the units that had a score equal to 1 in CRS and VRS models. The efficiency score distribution of VRS and CRS models is shown in Fig. 1. Clearly, these results suggest that the difference between efficient and inefficient farmers was caused by differences in consumption of inputs in vegetable greenhouse production. scale size. The last table column return to scale (RTS) - shows that all efficient DMUs (on the basis of TE) are functioning at constant return to scale (CRS), whereas the inefficient units are functioning at increasing return to scale (IRS), suggesting that there is need for significant adjustments in terms of yield and/ or agricultural management. The IRS indicates that an increase in output was achieved by an increase in input resources, which was higher than proportionate. The scale efficiency (SE) reached the value of 0.88 in average, indicating that with efficient input utilization, the inefficient farmers can save some energy from the various input sources without any changes in agricultural practices. There were no units functioning at decreasing return to scale (DRS). Nabavi-Pelesaraei et al. (2016) investigated the wheat production energy efficiency with similar results.

\section{Energy savings from different energy inputs}

Table 4 illustrates the optimal energy requirements and energy savings in greenhouse vegetable production on the basis of the CRS model. In addition to this, a contribution to the savings in energy is also provided.

As shown in Table 4, the calculations of the optimal energy

Table 4 Optimal energy requirements and energy savings for vegetable greenhouse production

\begin{tabular}{|l||c|c|c|c|}
\hline Input & $\begin{array}{c}\text { Optimal energy } \\
\text { requirement (MJ.ha-1 }\end{array}$ & $\begin{array}{c}\text { Saving energy } \\
\text { (MJ.ha- }\end{array}$ & $\begin{array}{c}\text { Saving } \\
\text { energy (\%) }\end{array}$ & $\begin{array}{c}\text { Contribution to the } \\
\text { savings in energy (\%) }\end{array}$ \\
\hline \hline Machinery & $1,379.93$ & 349.73 & $20.22 \%$ & $1.27 \%$ \\
\hline Diesel fuel & $4,680.45$ & 427.05 & $8.36 \%$ & $4.31 \%$ \\
\hline Infrastructure & $9,348.70$ & $12,660.24$ & $57.52 \%$ & $8.62 \%$ \\
\hline Fertilizers & $17,080.71$ & $9,909.98$ & $36.72 \%$ & $15.74 \%$ \\
\hline Farmyard manure & $12,050.57$ & $1,329.02$ & $9.93 \%$ & $11.11 \%$ \\
\hline Pesticides & $3,931.96$ & $8,232.49$ & $67.68 \%$ & $3.62 \%$ \\
\hline Electricity & $60,033.21$ & $24,621.16$ & $29.08 \%$ & $55.33 \%$ \\
\hline Total energy & $108,505.53$ & $57,529.66$ & $34.65 \%$ & $100.00 \%$ \\
\hline
\end{tabular}

Table 5 Improvement of energy indices for vegetable greenhouse production

\begin{tabular}{|l||c|c|c|c|}
\hline Indices & Unit & Actual quantity & Optimal quantity & Difference (\%) \\
\hline \hline Energy ration & - & $49 \%$ & $72 \%$ & 31.94 \\
\hline Energy productivity & $\mathrm{kg} \cdot \mathrm{MJ}^{-1}$ & 0.618162046 & 0.89941929 & 31.46 \\
\hline Net energy & $\mathrm{MJ} \cdot \mathrm{ha}^{-1}$ & $-92,992.09115$ & $-35,462.42738$ & 61.86 \\
\hline Specific energy & ${\mathrm{MJ} \cdot \mathrm{kg}^{-1}}$ & 1.6176988 & 1.1118285 & 31.67 \\
\hline
\end{tabular}


requirements for vegetable greenhouse production suggest that $108.50 \mathrm{GJ} \cdot \mathrm{ha}^{-1}$ in total can be saved in terms of machinery (1.38 GJ.ha $\left.{ }^{-1}\right)$; diesel fuel (4.68 GJ.ha $\left.{ }^{-1}\right)$; infrastructure (9.35 GJ.ha $\left.{ }^{-1}\right)$; fertilizers (17.08 GJ.ha $\left.{ }^{-1}\right)$; farmyard manure (12.05 GJ.ha- $\left.{ }^{-1}\right)$; pesticides (3.93 GJ.ha ${ }^{-1}$ ) and electricity (60.03 GJ.ha ${ }^{-1}$ ). Consequently approx. 35\% of total input energy in average can be saved if the farmers follow the recommendations provided in this study and maintain the current output level of greenhouse vegetable yield. Utilizing the similar methods, Firoozi et al. (2014) reported that, on average, $26.82 \%$ of the total input energy employed in greenhouse cucumber production in Iran can be saved.

\section{Improvements of energy indices}

Table 5 recapitulates the energy indices of actual and optimal quantities. The calculation demonstrates that the energy use efficiency is equal to 1.61 and 1.11 for actual and optimal quantities, respectively, with 0.51 of difference leading to an improvement of $31.67 \%$. Furthermore, by converting the current energy use index to target energy use index, the energy ration, energy productivity and net energy can be improved approx. by $31.94 \%, 31.46 \%, 19.82 \%$ and $19.80 \%$, respectively.

Nabavi-Pelesaraei et al. (2014) reported that the percentage of difference between target and optimal was approx. $24 \%$ for rice production.

\section{Conclusions}

This work is focused on optimization of the energy inputoutput for the protected crop production in Biskra province (South of Algeria) by means of the DEA approach. For this reason, a survey with 29 farmers was conducted.

Analysis adopted the significant inputs and assumed seven input variables: infrastructure; fertilizers; farmyard manure; electricity; diesel fuel; pesticides; and machinery energy - representing $91 \%$ of total energy used, as well as major energy inputs having significant impact on vegetable yield in the studied greenhouses.

The total energy necessary for protected crop production is $183.17 \mathrm{GJ}$ per hectare. The $51.72 \%$ of DMUs (15 units) was observed efficient on the basis of CRS model; the pure technical efficiency score equalled to 1 in terms of $79.31 \%$ of DMUs (23 units) on the basis of VRS model, indicating their efficiency.

The calculation demonstrates that the energy use efficiency is equal to 1.61 and 1.11 for actual and optimal units, respectively, with 0.51 of difference leading to an improvement of $31.67 \%$.

As recommendations, the following propositions can enhance the control over energy flow in protected vegetable production, as well as to allow the farmers to improve their financial situation; namely, providing farmers with training by a qualified person focused on improvement in their agricultural practices and enhancement of management over their inputs. Farmers should also improve the integrated pest management (IPM) by adoption of new methods for dealing with pests. In addition to these, awareness sessions for farmers regarding the effects of greenhouse gases on future generation should be elaborated.

\section{Acknowledgement}

This research was financially supported by the Scientific and Technical Research Centre for Arid Areas (CRSTRA), Biskra, Algeria. Gratitude is expressed to the agricultural specialists for their help in this work. Special thanks are extended to the farmers contributed in this survey.

\section{References}

ALLACHE, F. - BOUTA, Y. - DEMNATI, F. 2015. Population development of the tomato moth Tuta absoluta (Lepidoptera: Gelechiidae) in greenhouse tomato in Biskra, Algeria. In Journal of Crop Protection, vol. 4, no. 4, pp. 509-517.

AKPENPUUN, T. D. - MIJINYAWA, Y. 2018. Evaluation of a greenhouse under tropical conditions using Irish potato (solanum tuberosum) as the test crop. In Acta Technologica Agriculturae, vol. 21, no. 2, pp. 56-62.

BAHRAMI, H. - TAKI, M. - MONJEZIM, N. 2011. Optimization of energy consumption for wheat production in Iran using data envelopment analysis (DEA) technique. In African Journal of Agricultural Research, vol. 6, no. 27, pp. 5978-5986.

BANAEIAN, N. - OMID, M. - AHMADI, H. 2012. Greenhouse strawberry production in Iran, efficient or inefficient in energy. In Energy Efficiency, no. 5, pp. 201-209.

BANKER, R. D. - CHARNES, A. - COOPER, W.W. 1984. Some models for estimating technical and scale inefficiencies in data envelopment analysis. In Management Science, vol. 30, no. 9, pp. 1078-1092.

BELHADI, A. - MEHENNI, M. - REGUIEG, L. - YEKHLEF, H. 2016. Plasticulture contribution to agricultural dynamism in the Ziban region (Biskra). In Revue Agriculture, special issue 1, pp. 93-99.

BOJACÁ, C. R. - CASILIMAS, H. A. - GIL, R. - SCHREVENS, E. 2012. Extending the input-output energy balance methodology in agriculture through cluster analysis. In Energy, vol. 47, no. 1, pp. 465-470.

CHARNES, A. - COOPER, W. W. - RHODES, E. 1978. Measuring the efficiency of decision making units. In European Journal of Operational Research, vol. 1978, no. 2, pp. 429-444.

COOPER, W. W. - LI, S. - SEIFORD, L. M. - TONE, K. - THRALL, R. M. ZHU, J. 2001. Sensitivity and stability analysis in DEA: Some recent developments. In Journal of Productivity Analysis, vol. 15, no. 3, pp. 217-246.

EMROUZNEJAD, A. - PARKER, B. R. - TAVARES, G. 2008. Evaluation of research in efficiency and productivity: A survey and analysis of the first 30 years of scholarly literature in DEA. In Socio-Economic Planning Sciences, vol. 42, no. 3, pp. 151-157.

FIROOZI, S. - SHEIKHDAVOODI, M. J. - FARANI, S. M. 2014. Optimizing energy consumption efficiency for greenhouse cucumber production using the DEA (data envelopment analysis) approach in Markazi Province of Iran. In International Journal of Agricultural Technology, vol. 10, no. 3, pp. 543-558.

HATIRLI, S. A. - OZKAN, B. - FERT, C. 2006. Energy inputs and crop yield relationship in greenhouse tomato production. In Renewable Energy, vol. 31, no. 4, pp. 427-438.

HUGUENIN, J. M. 2013. Data Envelopment Analysis (DEA). A pedagogical guide for decision makers in the public sector. IDHEAP, Lausanne, France, 90 pp. ISBN 978-2-940390-56-4.

KIZILASLAN, H. 2009. Input-output energy analysis of cherries production in Tokat Province of Turkey. In Applied Energy, vol. 86, no. 7, pp.1354-1358.

MEDINA, A. A. - COOMAN, C. A. - PARRADO-SCHREVENS, E. 2006. Evaluation of Energy Use and Some Environmental Impacts for Greenhouse Tomato Production in the High Altitude Tropics. 
Netherlands University of Wageningen, pp. 415-422. ISBN 9789066056091.

MOHAMMADI, A - OMID, M. 2010. Economical analysis and relation between energy inputs and yield of greenhouse cucumber production in Iran. In Applied Energy, vol. 2010, no. 87, pp. 191-196. MOUSAVI-AVVAL, S. H. - RAFIEE, S. - JAFARI, A. - MOHAMMADI, A. 2011. Optimization of energy consumption for soybean production using Data Envelopment Analysis (DEA) approach. In Applied Energy, vol. 88, no. 11, pp. 3765-3772.

NABAVI-PELESARAEI, A. - ABDI, R. - RAFIEE, S. - TAROMI, K. 2014 Applying data envelopment analysis approach to improve energy efficiency and reduce greenhouse gas emission of rice production. In Engineering in Agriculture, Environment and Food, vol. 5, no. 2, pp. 207-218.

NABAVI-PELESARAEI, A. - HOSSEINZADEH-BANDBAFHA, H. - QASEMI-KORDKHEILI KOUCHAKI-PENCHAH, P. H. - RIAHIDORCHEH, F. 2016. Applying optimization techniques to improve of energy efficiency and GHG (greenhouse gas) emissions of wheat production. In Energy, vol. 16, no. 103, pp. 672-678.

NOURANI, A. - BENCHEIKH, A. 2017. Energy balance analysis and mechanization index for greenhouse vegetable production in southern of Algeria. An overview of Biskra province. In INMATEH Agricultural Engineering, vol. 51, no. 1, pp. 1-8.

OZKAN, B. - KURKLU, A. - AKCAOZ, H. 2004. An input-output energy analysis in greenhouse vegetable production: A case study for Antalya region of Turkey. In Biomass Bioenergy, vol. 29, no. 1, pp. 89-95.
PAHLAVAN, R. - OMID, M. - AKRAM, A. 2011. Energy use efficiency in greenhouse tomato production in Iran. In Energy, vol. 36, no. 12, pp. 6714-6719.

REYHANI-FARASHAH, H. - TABATABAEIFAR, S. A. - RAJABIPOUR, A. - SEFEEDPARI, P. 2013. Energy efficiency analysis of white button mushroom producers in Alburz Province of Iran: A data envelopment analysis approach. In Open Journal of Energy Efficiency, vol. 2, pp. 65-74.

REKIBI, F. 2015. Competitive analysis for tomato cultivation under greenhouse, case of study: Biskra province. Msc. Thesis. Mohamed Kheider University, Biskra. (In French: Analyse compétitive de la filière tomate sous serre. Cas de la Wilaya de Biskra)

SINGH, H. - MISHRA, D. - NAHAR, N. M. 2002. Energy use pattern in production agriculture of a typical village in arid zone India Part I. In Energy Conversion and Management, vol. 43, no. 16, pp. 2275-86.

SINGH, H. - MISHRA, D. - NAHAR, N. M. 2004. Energy use pattern in production agriculture of a typical village in arid zone India - Part III. In Energy Conversion and Management, vol. 45, no. 15-16, pp. 2453-2472. 